\title{
Translating Legal Collocations in Contract Agreements by Iraqi EFL
} Students-Translators

\author{
Muntaha A. Abdulwahid (Corresponding author) \\ Universiti Putra Malaysia, Malaysia \\ E-mail: muntaha.tuta20@yahoo.com \\ Zaitul Azma Binti Zainon Hamzah \\ Universiti Putra Malaysia, Malaysia \\ Pabiyah Hajimaming \\ Universiti Putra Malaysia \\ Hussein W. Alkhawaja \\ Universiti Putra Malaysia, Malaysia
}

Received: 20-12-2016

doi:10.7575/aiac.ijels.v.5n.1p.55
Accepted: 14-01-2017

Published: 31-01-2017

\begin{abstract}
Legal translation of contract agreements is a challenge to translators as it involves combining the literary translation with the technical terminological precision. In translating legal contract agreements, a legal translator must utilize the lexical or syntactic precision and, more importantly, the pragmatic awareness of the context. This will guarantee an overall communicative process and avoid inconsistency in legal translation. However, the inability of the translator to meet these two functions in translating the contract item not only affects the contractors' comprehension of the contract item but also affects the parties' contractual obligations. In light of this, the purpose of this study was to find out how legal collocations used in contract agreements are translated from Arabic into English by student-translators in terms of (1) purely technical, (2) semi-technical, and (3) everyday vocabulary collocations. For the data collection, a multiplechoice collocation test was used to be answered by $35 \mathrm{EFL}$ Iraqi undergraduate translator-students to decide on the aspects of weaknesses and strengths of their translation, thus decide on the aspects of correction. The findings showed that these students had serious problems in translating legal collocations as they lack the linguistic knowledge and pragmatic awareness needed to achieve the legal meaning and effect. They were also unable to make a difference among the three categories of legal collocations, purely technical, semi-technical, and everyday vocabulary collocations. These students should be exposed to more legal translation practices to obtain the required experience needed for their future career.
\end{abstract}

Keywords: legal meaning, legal collocations, contract agreements, student-translators, Iraqi student-translators

\section{Introduction}

\subsection{Translation of Legal Collocations}

The word 'collocation' is defined in Oxford Advanced Learner's Dictionary (2005, p. 293) as "a combination of words in a language that happens very often and more frequently than would happen by chance: 'resounding success' and 'crying shame' are English collocations". In legal contracts, collocations can take the same forms, but occur only in the context of a contract, such as 'price of contract'. These collocations might occur outside the legal context but they carry different meanings. The translation of legal collocations involves "combining the inventiveness of literary translation with the terminological precision of technical translation" (Harvey, 2002, p. 177). This is mainly because translating legal collocations used in legal documents, such as contracts, needs special type of wording, which must be precise and expressive in order to carry only the same interpretations as the ones meant in the legal context. Mohammad, Alawi, and Fakhouri (2010, p. 2) maintained that legal translation is characterized by "brevity, economy and neatness" and "[s]uch neatness and clarity is intended to prevent fraud, additions, omissions, or alterations in the text".

\subsection{Legal Meaning and Effect in Translating Contract Agreements}

Contracts are identified by WEBSTER (1998) as "[written] agreement[s] between two or more parties for the doing or not doing of something specified [which] are enforceable by law". In contract agreements, two functions must be 
achieved; (1) legal meaning and (2) legal effect (Sarčević, 1997). To achieve the legal meaning, a translator should follow a lexical or syntactic precision by relying on the linguistic knowledge he or she has to literally translate the legal text. Although translating legal text literally by following exactly the same style of the original is required and, to some extent, considered powerful, this might produce incomprehensible translation that is inconsistent with the original (Laybutt, 2009). To achieve a legal effect, a translator is required to possess pragmatic knowledge of the legal context, which helps him or her to differentiate between what is so called equivalence in meaning (semantic) and equivalence in legal effect (pragmatic). In her book, 'New Approach to Legal Translation', Šarčević (1997, p. 71) maintains that translators should realize two types of parallel legal texts; the first one should be "equal in meaning" and the other one should be "equal in legal effect". This kind of realization, thus, requires the translator "to produce a text that will lead to the same legal effects in practice". Šarčević, accordingly, indicates that the "basic unit of legal translation is the text, not the word" (p.5). In this sense, the terminological equivalence does play an essential role in translation, but 'legal equivalence' by which the relationships between the legal term and its context in the text are described is also of great importance (p.48).

\subsection{Categories of Legal Collocations}

Typologically, legal collocations are of three categories: (1) purely-technical, (2) semi-technical, and (3) everyday vocabulary collocations. Based on Alcaraz and Hughes (2014), purely technical collocations, such as 'discharge', 'price of contract', are those expressions that only exist in legal contracts and do not exist outside this boundary with the same meaning. These collocations have a semantic core meaning, which can be described as fixed or stable in translating contracts. This makes using these collocations is less problematic in translation, but they are essential for understanding the context of the translated text. semi-technical legal collocations, such as مصادق عليها (musadak alyha), which is translated into 'authenticated' in political documents, 'attested' in finance, 'endorsed' in the context of signing checks, consists of words and phrases borrowed from every day use or from other disciplines to be used in legal contexts. The additional legal meanings they acquired are a result of the need to these collocations to cover a new legal activity. These words are considered more complex to translators as they require the translators to semantically choose from a wide range of selections. This selection depends highly on the new legal context, which might result in differences among the translators. The everyday vocabulary collocations, such as وظيفة (wazifa), can be translated into 'job', 'position', 'occupation' or 'post'. The selection of the equivalent is completely dependent on contextual and pragmatic considerations. This requires taking into consideration the intended meaning of the original text and other stylistic and contextual limitations (Mohammad et al., 2010; Šarčević, 1997).

The problem arises with these categories when a translator does not differentiate between them and uses one of these types instead of another. This would not only affect the legal meaning of the collocation, but would affect the legal effect of the given collocation. To avoid such confusion, a translator is required to possess enough linguistic repertoire as well as pragmatic knowledge of the legal collocation context in the two languages: the source and target.

\subsection{Translating Contract Agreements in Iraq}

The great damage to the infrastructure in Iraq, which was caused by the consecutive wars, made the Iraqi government sign maintenance and reconstruction agreements with foreign companies. Contacting these companies is made through translating invitation contracts from Arabic to English, so they are understood by the foreign contracting companies. These contracts are usually translated by translators who work in local offices accredited by the Iraqi Translators Association. These offices also employ the new graduate students who follow the steps of the traditional translators in committing themselves to the lexical and syntactic equivalences of the source language while the communicative or pragmatic interpretation of translation is still beyond their scope. This phenomenon inspired the current researchers to investigate the current practices of the Iraqi EFL student-translators in translating the legal collocations in contract agreements.

\subsection{Research Problem}

Finding the equivalent meaning of SL text and write it in the TL text is not an easy task to accomplish, as it requires a translator to possess enough linguistic knowledge as well as cultural and social awareness in the source and target languages. It becomes even more difficult and challenging task when a translator involves in translating legal documents. This difficulty stems from the high demand of precision these documents requires. According to a number of researchers (Emery, 1989; Farghal \& Shunnaq, 1992; Garzone, 2000; Harvey, 2002; Šarčević, 1997), legal translation is one of the most difficult translation tasks for translation practioners. Mohammad et al. (2010, p. 70-71) posits that translators of legal texts must be capable of understanding " not only what the words mean and what a sentence means, but also what a legal effect is supposed to have, and how to achieve that legal effect in the other language". However, the inability of the translator to meet these two functions in translating the contract item would not only affect the contractors' comprehension of that item, but also it greatly affects the parties' contractual obligations. It is therefore important to investigate the current practices of EFL Iraqi student-translators in achieving the aforementioned functions while translating the collocations in legal contract agreements. This will help figure out the aspects of the problems that face these novice translators and convince them to adapt to the modern approaches of legal translation before joining their work. This will also help these students avoid committing the same old mistakes of sticking to literal translation and adapt to the modern communicative approaches. 
Previous research in this area has investigated various types of collocations in various fields, such as written sport reports (Laybutt, 2009), marriage contracts (Al Aqad, 2014), internet-based glossaries (Ilyas, 2015), everyday collocations (Faris \& Sahu, 2013), among others. Although these studies investigated various collocation contexts, the translation of legal contract agreements is still under investigation. It is therefore important to fill this gap in literature by focusing on legal contract agreements in order to inspect the student-translators' performance. This investigation will help analyze the aspects of these students' weaknesses and provide suggestions for improvement. The findings will also help improve these students' future translation practices.

\subsection{Research Questions}

The purpose of this study was to determine the overall performance of Iraqi EFL student-translators in translating legal collocations from Arabic into English and to find out the difficulties that face them in translating these collocations across the three collocation categories. The following research questions were asked accordingly:

1) What is the overall performance of the Iraqi EFL student-translators in translating legal collocations in contract agreements from Arabic into English?

2) What are the aspects of difficulties that face Iraqi EFL student-translators in translating legal collocations in contract agreements?

\section{Literature Review}

\subsection{Theoretical framework}

Translation process has witnessed a shift from relying on the linguistic approaches to relying on more functional, dynamic, and communicative approaches in the last three decades. Hans Vermeer in the 1970s used the term Skopos to refer to the purpose of translation (Reiß \& Vermeer, 1984). Han J. Vermeer proposed his Skopos Theory as a purposeoriented theory to shift the traditional translation into more functional and communicational one. He noted that translation process depends greatly on the function being communicated from the target text, which is, in certain cases, different from that existing in the source text. This is quite true as any text, especially the legal one, which is produced at a given time and place, and is intended to serve a specific function, is communicative in nature. This notion and new direction, as given by Vermeer, changed the direction of translations and opened the eyes of the new generations to consider pragmatics and context in translation. Accordingly, identifying the intended function of the source language becomes the priority and criterion for deciding upon the translation strategy and the type of collocation to be utilized. Following Vermeer's functional approach, Šarčević (1997, p. 71) maintains that translators should realize two types of parallel legal texts.; the first one should be "equal in meaning" and the other one should be "equal in legal effect". This kind of realization, thus, requires the translator "to produce a text that will lead to the same legal effects in practice". Accordingly, Šarčević noted that "the basic unit of legal translation is the text, not the word" (p.5). In this sense, the terminological equivalences do play an essential role in translation, but 'legal equivalence' by which the relationships between the legal term and its context in the text are described is also of great importance (p.48). In the current research, the Skopos Theory is adopted to underpin the interpretation of the students' answers in the legal collocation test. Accordingly, the legal meaning and legal effect were determined as resides in the students' selection of the equivalences.

\subsection{Review of Past Studies}

Legal translation from English to Arabic poses a number of difficulties that face legal translators. In a study conducted by El-Farahaty (2016), the researcher attempted to find out the common and lexical difficulties of translating legal texts between English and Arabic and to decide on the best translation procedures that should be followed by legal translators. By investigating a number of legal texts, El-Farahaty pointed out that the common aspects of difficulties lie in the difference in the terminology used in the two languages. The researcher noted that understanding the legal vocabulary of various kinds, such as the everyday, specialized, and functional ones in the two languages are very essential to produce a well-form legal translation. The translator also should possess the knowledge of the two language system to carefully investigate the translated texts. The researcher added that literal translation and transposition are useful techniques when translating doublets and triplets. Although this study pin pointed the differences between the source and target languages and the difficulties that might face the translators, it was limited to analyzing examples taken from various resources with a translation made by the researcher himself. A need for investigating an actual legal material is still needed.

Students-translators are the future translation practioners. Discovering their weaknesses in translation as well as their sources at early stages of their translation journey will help them avoid committing the same mistakes in the future. Farghal and Shunnaq (1992) conducted a study that investigated the translation ability of Arab Jordanian university students to translate the United Nations legal documents. The researchers focused on identifying the problematic areas in translating these documents by MA translation students at Yarmouk University during their comprehensive examination. According to the researchers, the students encountered great problems especially in three aspects of translation. These aspects were classified by the researchers into syntax, layout, and tenor-related problems. The reasons were ascribed by the researchers to students' lack of awareness of the asymmetry in using infinitives in English, ignorance of tabulation and italics, and misuse of lexi-ecological choices that alters the formal character of the text 
vocabulary. As it can be seen, this research focused on the fidelity and accuracy of semantics and syntax while the focus on pragmatics was not paid any attention. Moreover, the research handled one type of legal documents which is the United Nations legal documents. A need for investigating the students-translators performance in translating other legal documents, such as legal contract agreement, is also of equal importance.

Faris and Sahu (2013) hypothesized that the Iraqi EFL student-translators face difficulties in translating the English collocations into Arabic. The focus of the study was on finding the errors these students made and the causes of these errors. For this purpose, the researchers asked 20 fourth-year College students in Iraq to translate 15 sentences that have collocations from English to Arabic. The test results showed that $70 \%$ of these students face difficulties in the translation of English collocations into Arabic. The difficulties were found related to three major areas: overgeneralization, the variability of collocations, and the cultural-based idiomatic collocations. These difficulties, which led to committing errors in translation, were ascribed by the researchers to the cultural differences between the two languages systems. Other causes mentioned by the researchers included the inability of the Arab learners to find certain equivalences for the English collocations, the word-by-word translation method, the differences in the grammatical structure (forms) between Arabic and English, and their ignorance of the context of English collocation. Faris and Sahu's study is important as it attempted to find some of the problematic areas that face students in translating collocations and the possible causes of these problems. Nevertheless, their study was limited to everyday collocations. No attention was given to investigate more specialized collocation, such as the legal colocation in contract agreement, a gap that is filled in the current thesis.

\section{Methods}

\subsection{Research design}

This study adopted a descriptive analytical approach which employed quantitative (i.e., statistical) and qualitative (i.e., analytical) approaches for data collection and data analysis. The selection of this design for the current study was made based on previous research that used similar design (Faris \& Sahu, 2013; Mohammad et al., 2010). This design was suitable as it enabled researchers to collect two types of data, qualitative and quantitative, in which the quantitative data were statistically presented to guide the qualitative interpretations. Gay and Airasian (2003, p. 277) noted that mixedmethod design is "useful for investigating a variety of educational problems, and concerned with assessing attitudes, opinions, preferences, demographics, practices, and procedures". Alaugab (2007) pointed out that that mixed-method research designs are helpful in achieving the objectives of the study because they provide with a comprehensive presentation of the data, thus providing answers to the research questions regarding the various aspects of learners' attitude. The qualitative interpretation of the data in the present study followed a linguistic as well as pragmatics approaches to better understand the linguistic use of the collocations in relation to the context of the these collocations as occurred in the contract agreement. The use of this approach helped understand the translation produced by three of accredited translators as well as the student-translators.

\subsection{Subjects}

The subjects are 35 Iraqi undergraduate student-translators. They speak Arabic as the first language and study English as the foreign language. They attend a translation class at the College of Languages / University of Baghdad in Iraq. The sampling, (i.e., the procedures of recruiting a definite number of subjects to participate), was made through a nonprobability sampling procedure known as convenience sampling. According to Creswell (2013), the selection of this type of sampling can be made when the randomization of the subjects is not possible. It is also used when the selection of the sample is dependent on the availability of the students. In this study, and after obtaining the required permissions from the students' Faculty, these subjects were first contacted in their class. At this stage, the general idea of the study as well as the task in the test was explained to them. They were then asked to answer the questions.

\subsection{Data Collection Instrument and Procedures}

The main instrument used for data collection is a 15-question collocation test designed by the researcher. The aim of the collocation test was to determine the current Iraqi student-translators' translation performance of legal collocations that are used in translating legal contract agreements. The test consists of 3 parts in which 5 questions that measure the students' performance in one of the collocation types: purely technical, semi-technical, and everyday vocabulary collocations were under investigation. Each question consists of a stem and 4 options in the format of a multiple choice. To design the test, the 15 collocations were first selected from a contract agreement between the Iraqi Ministry of Electricity and one of the foreign construction companies. Next, four options were written based on three translations provided by three Iraqi translation practioners, who are accredited by the Iraqi Translators Association. Each of the questions in the tests starts with a contract item extracted from the contract agreement. These items were written in Arabic (Source Language) and translated into English (Target Language). After each contract item, four options were given to the students in which one option out of four was correct. The selected students in this study were asked to provide answers to the questions by selecting the correct option.

\subsection{Data Analysis}

After marking the students' answers, the scores were uploaded into an Excel worksheet to calculate the frequency and percentages of the correct/incorrect answers. The analysis was conducted then at three levels: at the overall translation 
performance, at the specific category of collocation, and at the specific option in each category. The purpose of this hierarchy analysis was to trace the various aspects of the problem.

\section{Results and Discussion}

The following are the findings and analysis of the students' performances.

\subsection{Results of the First Research Question}

The first research question asked about the overall Iraqi student-translators' performance in translating legal collocations. The analysis of the students' answers in the collocation test (Table 1) showed that, on average, only $27 \%$ of the students selected the correct option to answer the 15 questions. However, $73 \%$ of the students selected the wrong translation option.

Table 1. Overall Students’ Performance in Translating Legal Collocations

\begin{tabular}{lll}
\hline Options & Answers & Percentage \\
\hline Total Correct & 142 & $27 \%$ \\
Total Incorrect & 383 & $73 \%$ \\
\hline Total Answers & 525 & $100 \%$ \\
\hline
\end{tabular}

A close inspection of the students' answers of each category shows that the students face more problems in translating the purely-technical collocations (Table 2). This is clear when only $25 \%$ of the students translated the five collocations in this category correctly and $75 \%$ of the students selected the incorrect options $(2,3$, and 4 ). Similarly, $26 \%$ of the students translated the five collocations in the semi/mixed technical collocations category correctly, whereas $74 \%$ of them selected the wrong translations. However, the correctness level rose up to $30 \%$ when the students were asked to translate the five collocations in the everyday category.

Table 2. Students' performance in translating each category of legal collocations

\begin{tabular}{lllll}
\hline Collocation Categories & Correct option 1 & Incorrect option 2 & Incorrect option 3 & Incorrect option 4 \\
\hline Purely technical collocations & 44 & 57 & 39 & 35 \\
& $25 \%$ & $33 \%$ & $22 \%$ & $20 \%$ \\
Semi/mixed technical collocations & 45 & 44 & 43 & 43 \\
& $26 \%$ & $25 \%$ & $25 \%$ & $25 \%$ \\
Everyday collocations & 53 & 37 & 39 & 46 \\
& $30 \%$ & $21 \%$ & $22 \%$ & $26 \%$ \\
\hline
\end{tabular}

\subsection{Discussion of the First Research Question}

The aforementioned results demonstrate that the students generally do have a major problem in the translation of the legal collocations that are used in the contract agreements. This is clear from their low performance across all the three categories of collocation: purely technical, mixed-technical, and everyday vocabulary. These results are consistent with the results reached by Faris and Sahu (2013), who found that $70 \%$ of the fourth-year College Iraqi students face difficulties in the translation English collocations into Arabic. The results also demonstrate that the students' problems increase towards translating collocations that are more technical in nature. This is clear when they committed more mistakes across the purely as well as the semi/mixed technical categories of collocations than they did in translating the everyday collocations. The findings of this study conform with the findings by Shammas (2013), who investigated the translation of collocation by 96 postgraduate Arab learners of English. Shammas found that, although everyday collocations are easy to translate, the students committed a huge number of mistakes in translating this type of collocations.

\subsection{Results of the Second Research Question Aspects of difficulties in translating each category of legal collocations} (RQ2)

The second research question asked about the aspects of difficulties that contributed to their poor translation performance and the difficulties in translating each category of legal collocations.

\subsubsection{Difficulties in Translating Purely Technical Collocations}

In question 1, the students were asked to translate the collocation التعويضات المقطوعة (alta’wīḍati almaqtū'ata) into English in the following contract item: 
(SL)

(TL) The

$$
\text { يجب دفع التعويضات المقطوعة عن التاخير لكل يوم من قبل الطرف الثناني. }
$$

shall be paid for the delay of each day by the second party.

This collocation refers to the sum of money that is paid compulsory as a penalty of delay in work implementation. The analysis (Table 3 ) showed that $31 \%$ of the students were able to render the correct translation. The analysis also showed that $43 \%$ of the students translated this collocation literally into 'cut compensations'. The students dealt with this collocation as an everyday collocation by using literal translation of each of the words as given in Arabic. Another mistake was made by $11 \%$ of the students, who used the same equivalence 'compensations' to render the Arabic word التعويضات (alta'wīẹtati). However, they translated the first part of the collocation into its function as the 'paid' money. Although the translation of this collocation as 'paid compensations' achieved the legal meaning, it failed in achieving the implied legal effect of 'penalty'. Another group of students (14\%) selected 'fixed damages' based on the idea that the damages caused by the constructor are already agreed upon or 'fixed' in the contract. However, the use of the 'compensation' and damages does not exist in legal dictionaries, such as Benson, Benson, and Ilson (2009) or Almaany.com (2016).

Table 3. Question One

\begin{tabular}{|c|c|c|c|c|}
\hline $\mathrm{SL}$ & Transl. & TL Options & Answers & Percent. \\
\hline \multirow{5}{*}{ التعويضنات } & \multirow{5}{*}{$\begin{array}{l}\text { alta'wīḍati } \\
\text { almaqūuata }\end{array}$} & liquidated damages & 11 & $31 \%$ \\
\hline & & cut compensations & 15 & $43 \%$ \\
\hline & & paid compensations & 4 & $11 \%$ \\
\hline & & fixed damages & 5 & $14 \%$ \\
\hline & & Total & 35 & $100 \%$ \\
\hline
\end{tabular}

In question 2, the students were required to translate the collocation المو اصفات الفنية (Almuwasafati alfanīyati) into its English equivalence:

(TL) The second party shall provide the materials and tools special for civil works in accordance with the

This collocation refers to the set of technical standards set forth prior to work implementation. The analysis showed that $20 \%$ of the students could render the correct translation (Table 4). These students used the collocation 'technical specifications', which can reflect the legal meaning and effect of the given collocation. Although two groups of the students used the word technical to translate the word المو اصفات (alfaniyati), they failed in finding the equivalence of (Almuwasafati). One of the groups (26\%) used the word 'qualifications' and another one (37\%) used the word 'descriptions'. Although the use of these words can give the meaning of المواصفات, they cannot achieve the legal effect of the word 'specification'. While the word 'specification' carries the meaning of the 'agreed upon standards' between the two contracting parties, the word 'qualifications' is used in the education field and the word 'descriptions' is usually used to describe someone or something and has nothing to do with any technical specifications. The last group of students (17\%) used 'artistic qualities'. The word 'artistic' is used with the work of art and the word 'qualities' is used to refer to the characteristics of someone or something, which makes the students' selection inaccurate.

Table 4. Question Two

\begin{tabular}{|c|c|c|c|c|}
\hline SL & Trans. & TL Options & Answers & Percent. \\
\hline \multirow{4}{*}{ المو اصفات الفنية } & \multirow{4}{*}{$\begin{array}{l}\text { Almuwasafati } \\
\text { alfanīyati }\end{array}$} & technical specifications & 7 & $20 \%$ \\
\hline & & artistic qualities & 6 & $17 \%$ \\
\hline & & technical qualifications & 9 & $26 \%$ \\
\hline & & technical descriptions & 13 & $37 \%$ \\
\hline & & Total & 35 & $100 \%$ \\
\hline
\end{tabular}

In Question 3, the students were asked to translate the legal collocation ضمانات الاداء (damanati alada') into its English: 
(SL)

(TL) The first party shall release all

$$
\text { يقوم الطرف الاول بتحرير كل ضمانات الاداء عند انتهاء فترة الضمان كما هو محدد في العقد. }
$$

upon the completion of guarantee period as specified in the contract.

The analysis of this contract item (Table 5) showed that only $20 \%$ of the student-translators used the correct equivalent 'performance bonds'. In the context of contract agreement, the use of this collocation is solely to refer to the documents that are released or issued by the contractor as a guarantee or warranty of good work implementation. However, the rest of the students used the literal meaning of the word ضمانات (damanati) by using 'guarantees' (29\%), 'securities' (29\%), and 'warranties' $(23 \%)$. Although the use of these words reflected the legal meaning of the collocation, they failed in reflecting the legal effect of 'obligation' expressed by the word 'bond'.

Table 5. Question Three

\begin{tabular}{lllll}
\hline SL & Trans. & TL Options & Answers & Percent. \\
\hline & & performance bonds & 7 & $20 \%$ \\
& & performance guarantees & 10 & $29 \%$ \\
damanati alada’ & performance securities & performance warranties & 10 & $29 \%$ \\
& & Total & 8 & $23 \%$ \\
\hline & & & 35 & $100 \%$ \\
\hline
\end{tabular}

In question 4, the students were asked to translate the collocation بوليصة الثحن (Būlīṣata Ashahni) into English:

$$
\text { على الطرف الاول اكمال اجر اءات التخليص الكمركي للبضائع المستوردة وختم بوليصة الثحن. }
$$

(TL) The first part shall complete the customs clearance procedures and stamp the

The analysis (Table 6) showed that $34 \%$ of the students used the collocation 'bill of lading', which is a document that regulates the relationship between the transporter and receiver. The students' correct selection is likely due the frequent use of the word in various legal fields. Nevertheless, $26 \%$ of students confused this collocation with 'shipment list', another group of students (26\%) used the expression 'charging list', and the last group used 'bill of shipment'. The three groups used totally different words that refer to different types of documents. This confusion might have been caused to them because of the word الثحن (Ashahni) which can be translated literally into 'shipment' or 'charging'.

Table 6. Question Four

\begin{tabular}{cllll}
\hline SL & Trans. & TL Options & Answers & Percent. \\
\hline & & bill of lading & 12 & $34 \%$ \\
& bülīșata Ashahni & bill of shipment & 5 & $14 \%$ \\
& & shipments List & 9 & $26 \%$ \\
& & charging List & 9 & $26 \%$ \\
\hline & & Total & 35 & $100 \%$ \\
\hline
\end{tabular}

In the last question under this category (5), the students were required to translate the collocation تسليم مفتاح (Taslimm Muftah) into its English equivalence:

$$
\text { يشتمل هذا العقد على تصميم محطات ثانونيه بطاقة 132\33 كيلو فولت ( تسليم مفتاح ) في المو اقع التاليه: }
$$

(TL) This contract includes the design of sub-stations with a capacity of 132/33 KV ( ) in the following sites:

The analysis of the students' answers (Table 7) showed that $29 \%$ of the students used the correct collocation 'turnkey', which refers to the type of contract that ends with a complete implementation of construction including the import of material, construction, and finishing. The same percentage of students (29\%) used 'turning key'. The use of this expression is not accurate as the use of the gerund 'turning' carries the meaning of the process that can be performed by 
a key, which is not meant in the given context of collocation. The rest of students did not select the right answer as they used either 'key delivery' (17\%) or 'key submittal' (26\%). Although these words carry the legal meaning of (Taslīm), which can be translated into English as 'delivery' or 'submittal', the use of these words did not achieve the legal effect intended in the context of the item.

Table 7. Question Five

\begin{tabular}{|c|c|c|c|c|}
\hline SL & Trans. & TL Options & Answers & Percent. \\
\hline \multirow{5}{*}{ تسليم مفتاح } & \multirow{5}{*}{ Taslīm Muftah } & turnkey & 10 & $29 \%$ \\
\hline & & key delivery & 6 & $17 \%$ \\
\hline & & turning key & 10 & $29 \%$ \\
\hline & & key submittal & 9 & $26 \%$ \\
\hline & & Total & 35 & $100 \%$ \\
\hline
\end{tabular}

\subsubsection{Difficulties in Translating Semi-Technical Collocations}

In question 6, the students were asked to translate the semi-technical collocation سير العمل (Sayri Al'amal) into English:

$$
\text { بالنسبه لاعمال التصميم، يتم دفع } 85 \text { \% من سعر العقد عند تقديم قائمة الاسعار مع التقارير الثهريه لسير العمل }
$$

(TL) For design works, $85 \%$ of the contract price shall be paid at the submittal of the price list, along with the monthly reports of

This collocation carries the legal meaning of 'advancement in work'. It also refers to the legal effect of 'work continuity'. This collocation can be found in both legal and administrative discourse. The analysis of this question (Table 8) showed that the first group of students (11\%) used the collocation 'work progress', which achieves both the legal meaning and effect of the collocation. However, the second group (60\%) used the expression 'work movement', which neither expresses the legal meaning nor reflects the legal effect. They, instead, used the word 'movement' as a literal translation of the Arabic word سير (Sayri) referring to the movement form place to another, which does not exist in the context of the contract term. The second group (14\%) used the word 'continuity' which literally carries the legal meaning of سير (Sayri). However, the use of this word does not carry the legal effect of 'progress' as intended by the context of the contract term. The third group (14\%) used the expression 'advancement' which carries another alternative to the legal meaning of سير (Sayri). However, the use of 'work advancement' does not exist in legal dictionaries, such as Benson et al. (2009) or Almaany.com (2016).

Table 8. Question Six

\begin{tabular}{lllll}
\hline SL & Trans. & TL Options & Answers & Percent. \\
\hline Sayri Al'amal & work progress & 4 & $11 \%$ \\
& & work movement & 21 & $60 \%$ \\
& work continuity & 5 & $14 \%$ \\
& work advancement & 5 & $14 \%$ \\
\hline
\end{tabular}

In question 7, the students were asked to translate مؤكدة وغير قابلة للنقض (Muakadah wa ghair qabilah linnaqḍ) into English:

$$
\text { على الطرف الثاني فتح خطابي ائتمان مؤكدة وغير قابلة للنقض بالدو لار. }
$$

(TL) The second party shall open two letters of credit that are and in USD.

The analysis of the students' answers (Table 9) showed that $37 \%$ of the students used the collocation 'affirmed and irrevocable', which reflects the intended legal meaning and effect. The use of the word 'affirmed', which describes the letter of credit (LC) that cannot be changed after issuing; whereas, the use of the word 'irrevocable' is used to stress that the LC is issued permanently without any possibility of future cancellation. In this case, the two words form a collocation that has the legal effect of unchangeable action, thus considered correct. Another group (17\%) used the 
collocation 'stressed and incontestable', which can be used in courts to refer to the undisputable judgment. In this sense, this collocation does not meet the legal effect in the contract agreement, thus considered faulty. Around 34\% of students used the collocation 'confirmed and irrefutable', which is also faulty as it is used to describe opinions in everyday life. The last group (11\%) used the 'approved and contradictable', which are general words that are borrowed from an everyday vocabulary usage.

Table 9. Question Seven

\begin{tabular}{lllll}
\hline SL & Trans. & TL Options & Answers & Percent. \\
\hline & & affirmed and irrevocable & 13 & $37 \%$ \\
\multirow{3}{*}{ مؤكدة غيلة } & Muakadah ghair & stressed and incontestable & 6 & $17 \%$ \\
& qabilah linnaqd & confirmed and irrefutable & 12 & $34 \%$ \\
& & approved and contradictable & 4 & $11 \%$ \\
\hline & & Total & 35 & $100 \%$ \\
\hline
\end{tabular}

In question 8, the student were asked to translate the Arabic collocation الاصول المؤكدة (Alusūl almuakadah) into English:

$$
\text { على الطرف الثاني تجهيز المواد والمعدات الخاصة بالاعمال المدنية بموجب الاصول المؤكدة في المناقصة. }
$$

(TL) The second party shall supply the material and tools special for the civil works in accordance with the in the tender.

The analysis (Table 10) showed that $40 \%$ of the students rendered the exact translation of the given collocation as 'affirmed assets'. The word الاصول (Alusūl), which is used in various legal fields, such as finance, commerce, or construction agreements, carries the legal meaning of the valuable resources that one of the parties possesses, such as the equipment, tools, or machines. This word can only be translated as 'assets'. However, a number of students (14\%) used the collocation 'approved originals'. This translation is faulty because the plural word 'originals' is a literal translation of the given word الاصول (Alusūl), which refers to the 'genuine things' that is not meant in the text. Another group of students (17\%) used the collocation 'accepted rules', which has nothing to do with the given collocation in the item. Although the last group used the word 'affirmed' to translate the word المؤكدة (almuakadah), which is correct, they used the word 'essentials', which is completely wrong literal translation of the word الاصول (Alusūl). The students in this group literally translated the meaning of الاصصول (Alusūl) because one of the meanings of this Arabic word is 'essential'.

Table10. Question Eight

\begin{tabular}{lllll}
\hline SL & Trans. & TL Options & Answers & Percent. \\
\hline الاصول المؤكدة & Alusūl almuakadah & affirmed assets & 14 & $40 \%$ \\
& & approved originals & 5 & $14 \%$ \\
& & accepted rules & 6 & $17 \%$ \\
& & affirmed essentials & 10 & $29 \%$ \\
\hline
\end{tabular}

In question 9, the students were asked to translate the Arabic collocation ملزما نافذا (mulziman nafidhan) into English:

(SL)

(TL) This contract shall be

$$
\text { سيكون هذا العقد ملزما نافظا عند التوقيع عليه من قبل كلا الطرفين. }
$$
once it is signed by the two parties.

The analysis (Table 11) showed that $17 \%$ of the students used the correct collocation 'obligatory and in force'. The translation of the first part of this collocation requires achieving the legal effect of 'commitment' expressed by the word 'obligatory'; whereas, the second part of the collocation requires achieving the legal effect of 'operation', which can be expressed by the prepositional phrase 'in force'. However, $46 \%$ of the students used 'obligatory and valid'. The first part 'obligatory' is correct while the second word 'valid' refers to the legal acceptability of the contract, which is not meant in the contract item. The other two groups used 'mandatory and effective' (17\%) and 'mandatory and valid' 
$(20 \%)$. While 'mandatory' can be an alternative of the right word 'obligatory', the words 'effective' is used with laws and the word 'valid' is used with 'legal acceptability'.

Table 11. Question Nine

\begin{tabular}{lllll}
\hline SL & Trans. & TL Options & Answers & Percent. \\
\hline mulziman nafidhan & obligatory and in force & 6 & $17 \%$ \\
& & obligatory and valid & 16 & $46 \%$ \\
& mandatory and effective & 6 & $17 \%$ & $20 \%$ \\
\hline & mandatory and valid & 7 & $100 \%$ \\
\hline
\end{tabular}

In question 10, the students were asked to translate the semi-technical collocation خطاب تسهيل مهمة (Khitabu tashīli muhimmatin) into English:

$$
\text { على الطرف الثاني طلب خطاب تسهيل مهمة مثرجم الى اللغة العربيه من قبل الطرف الاول. }
$$

(TL) The second party shall request translated into Arabic from the first party.

The analysis showed that only $14 \%$ of the students were able to translate the collocation خطاب تسهيل مهمة (Khitabu tashīli muhimmatin) correctly by using 'a letter of task facilitation'. Another group of students (26\%) translated the first part خطاب تسهيل مهمة (Khitabu) correctly into 'a letter of'. However, they wrongly translated the second part muhimmatin) into 'to make the task easy', which is a literal translation of the given collocation. The other two groups were not able to translate either part of the collocation. One of them (29\%) used 'a report of' instead of 'a letter of' and the other used 'to make the task easy' instead of 'task facilitation'. The use of these expressions is considered faulty for two reasons. First, the word 'report' is used to refer to the documents released after task completion, which is not the case in the given contract item. Second, 'to make the task easy' is a literal translation that can only achieve the legal meaning not the legal effect expressed by 'facilitation', which implies 'smoothness of task execution' not its easiness. The second group (31\%) used 'a speech of' instead of 'a letter of', which is completely wrong because the word 'speech' is used in oral correspondence. They also used 'task easiness' instead of 'task facilitation'. The expression 'task easiness' is used to refer to the easiness of task not its effect in smoothing the execution of the task.

Table 12. Question Ten

\begin{tabular}{|c|c|c|c|c|}
\hline SL & Trans. & TL Options & Answers & Percent. \\
\hline \multirow{5}{*}{ خطاب تسهيل } & \multirow{5}{*}{$\begin{array}{l}\text { Khitabu tashīli } \\
\text { muhimmatin }\end{array}$} & a letter of task facilitation & 5 & $14 \%$ \\
\hline & & a speech of task easiness & 11 & $31 \%$ \\
\hline & & a report to make the task easy & 10 & $29 \%$ \\
\hline & & a letter to make the task easy & 9 & $26 \%$ \\
\hline & & Total & 35 & $100 \%$ \\
\hline
\end{tabular}

\subsubsection{Difficulties in Translating Everyday Vocabulary Collocations}

In question 11, the students were asked to translate the everyday vocabulary collocation اتخاذ التدابير المناسبة (itikhadhu atadabīri almunasibahti) into English:

$$
\text { في مثل هذه الظروف، للطرف الثاني اتخاذ التدابير المناسبة لحمايه موظفيه و العدد و المعدات. }
$$

(TL) In such circumstances, the second party has the right to to protect his employees, tools, and equipment.

In this contract item, the second party is required to do his best to protect his employees, tools, and equipment by taking effective procedures. The analysis (Table 13) showed that $31 \%$ of the students rendered the accurate equivalence of the collocation by using 'take proper procedures'. The second group $(20 \%)$ used the collocation 'take proper measures'. Although the word 'measures' is used to express the actions in case of problems, it is used only before the problem occurs as a precaution. This makes the word 'procedures' more appropriate in the context of the given contract item 
because the procedures are required to be taken after the problem occurs and they are much connected with existence of a threat or a problem. The third (14\%) and fourth groups of students (34\%) used 'behave properly' and 'measure properly' respectively. By using the word 'properly', these two groups underestimated the legal effect of action that shall be taken. They also used 'behave' and 'measure' which cannot be used in a legal context because the word 'behave' is used in moral and personal issues while the word 'measure' is used as a verb that is used with measurements.

Table 13. Question Eleven

\begin{tabular}{lllll}
\hline SL & Trans. & TL Options & Answers & Percent. \\
\hline اتخاذ التدابيرة & itikhadhu atadabīri & take proper procedures & 11 & $31 \%$ \\
& almunasibahti & take proper measures & 7 & $20 \%$ \\
& & behave properly & 5 & $14 \%$ \\
& & measure properly & 12 & $34 \%$ \\
\hline & Total & 35 & $100 \%$ \\
\hline
\end{tabular}

In question 12, the students were asked to translate the collocation بذل الجهود (Badhlu aljuhūdi) into English:

(SL)

(TL) The two parties shall

$$
\text { على الطرفين بذل الجهود لتسوية اية اختلافات او نزاعات تنشا من العقد. }
$$
to settle any disagreements or dispute that emerge from the contract.

This collocation consists of the verb 'exert' and the noun 'efforts'. The use of these words expresses the legal effect of 'doing the uttermost of effort' that ends with giving solutions in case of a dispute that might arise between the two parties. The analysis (Table 14) showed that $31 \%$ of the students rendered the most accurate equivalent collocation 'exert all the efforts'. The translation provided by the other three groups of students was able to communicate the meaning expressed by the collocation. However, their translation was not able to communicate the legal effect of exerting the uttermost level of efforts to sort out the raised problems. The second group (23\%) used 'offer solutions' which limits the efforts to offering solutions while the implication of exerting the uttermost is not expressed. The third group of $(29 \%)$ seems to realize the legal effect expressed in the collocation. However, they translated it literally into 'do the maximum', which is a non-standard expression of 'exerting efforts'. For the fourth group of students (17\%), they used the collocation 'work hard'. The use of 'work hard' in English is much related to the efforts exerted in jobs or works which expresses the legal meaning, but did not communicate the legal effect expressed by exerting all the efforts in sorting out problems.

Table 14. Question Twelve

\begin{tabular}{lllll}
\hline SL & Transliteration & TL Options & Answers & Percent. \\
\hline Badhlu & aljuhūdi & exert efforts & GR1 (11) & $31 \%$ \\
& & offer solutions & GR2 (8) & $23 \%$ \\
& & do the maximum & GR3 (10) & $29 \%$ \\
& work hard & GR4 (6) & $17 \%$ \\
\hline
\end{tabular}

In question 13, the everyday vocabulary collocations كليا اوجزئيا (kullyan aw juziyan) was under translation:

$$
\text { لايستطيع الطرف الثاني العودة عن او تحويل حقوقه التعاقدية كليا اوجزئيا الى طرف ثالث. }
$$

(TL) The second party shall not decline or transfer his contracting rights to a third party.

The analysis (Table 15) showed that $31 \%$ of the students translated the collocation into 'wholly or partially' correctly. The grammatical form of this collocation is an ADV + ADV. These adverbs describe the action 'transferring the contracting rights to a third party' by defining its quantity. So, the legal meaning is the 'quantity' and the legal effect is the 'optionality' of the quantity selection. However, the other three groups of student-translators did not apply the grammatical rule of using two adverbs. The second group $17 \%$ used two adjectives 'whole or part', the third group 
$(26 \%)$ also used two adjectives 'all or part', and the fourth group (26\%) used an adverb and an adjective, which are all considered incorrect as they do not use two adverbs to define the quantity.

Table 15. Question Thirteen

\begin{tabular}{|c|c|c|c|c|}
\hline SL & Trans. & TL Options & Answers & Percent. \\
\hline \multirow[t]{5}{*}{ كليا اوجزئيا } & kullyan & wholly or partially & 11 & $31 \%$ \\
\hline & aw & whole or part & 6 & $17 \%$ \\
\hline & juziyan & all or part & 9 & $26 \%$ \\
\hline & & partly or all & 9 & $26 \%$ \\
\hline & & Total & 35 & $100 \%$ \\
\hline
\end{tabular}

In question 14, the students were asked to translate the collocation يخضع لـ (Yakhdha'u li) from Arabic into English.

(SL)

(TL) This contract

$$
\text { يخضع هذا العقد لِكل التعليمات و القو انين النافذة في جمهوريه العر اق. }
$$

all instructions and valid laws in the Republic of Iraq.

Although the grammatical form of this collocation in Arabic is a verb + preposition, the grammatical form of this collocation in English consists of an auxiliary (is) followed by an adjective (subject), and a preposition (to). This combination carries the meaning of 'goes under the control of', which can be translated using the collocation 'is subject to'. The analysis (Table 16) showed that $26 \%$ of the student-translators used the correct equivalence to the collocation يخضع لـ (Yakhdha'u li) using 'is subject to'. However, the second group (20\%) used the verb 'subjects' and the preposition 'to', whereas, the third group (29\%) used the auxiliary 'is', the past participle 'subjected' and the preposition 'to'. These two groups were confused between using the word 'subject' as a verb or as an adjective as the word 'subject' can be both depending on the linguistic context. The fourth group (29\%) used the verb 'submits' which neither achieved the legal meaning nor the legal effect.

Table 16. Question Fourteen

\begin{tabular}{lllll}
\hline SL & Trans. & TL Options & Answers & Percent. \\
\hline$\lrcorner$ يخضع & Yakhdha'u li & is subject to & 9 & $26 \%$ \\
& & subjects to & 7 & $20 \%$ \\
& is subjected to & 10 & $29 \%$ & $26 \%$ \\
\hline & submits & 9 & $100 \%$ \\
\hline
\end{tabular}

In the last question (15) about the everyday vocabulary collocations, the students were asked to translate the collocation (istinadan ila) from Arabic into English.

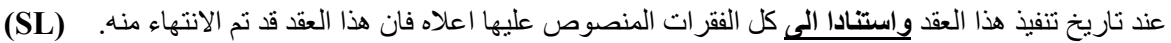

(TL) At the date of this contract implementation and all the listed paragraphs above, this contract has been completed.

In this last question, the targeted collocation was the prepositional phrase 'on the basis of' which consists of (PRE). This collocation achieves the meaning of 'depending on'. It can be translated as 'on the basis of' followed by a noun. The analysis of the students' answers showed that $31 \%$ of the students selected this collocation correctly using 'on the basis of'. The second group (17\%) used 'basis on' which is grammatically incorrect confusing it with 'based on'. This group was not able to make a difference between the Adj 'based on' and the noun 'basis'. The third group (32\%) used the phrasal verb 'rely on' which does not suit the linguistic context of using a gerund. If the subjects used the gerund 'relying' in addition to the preposition 'on', the use would be correct. The last group of students used the preposition 'with reference to', which is used in English to mean 'concerning', which is not intended in the contract item. What is intended in the contract item is to establish a point of reference to rely upon, not just referring to it. 
Table 17. Question Fifteen

\begin{tabular}{|c|c|c|c|c|}
\hline SL & Transliteration & TL Options & Answers & Percent. \\
\hline \multirow[t]{5}{*}{ استنادا الى } & istinadan ila & on the basis of & 11 & $31 \%$ \\
\hline & & basis on & 6 & $17 \%$ \\
\hline & & rely on & 8 & $23 \%$ \\
\hline & & with reference to & 10 & $29 \%$ \\
\hline & & Total & 35 & $100 \%$ \\
\hline
\end{tabular}

\subsection{Discussion of the Second Research Question}

The aforementioned results demonstrate that the mistakes committed by the students in translating the purely technical collocations are due to the students' unfamiliarity with the legal terminologies and their lack the experience in translating such kind of technical collocations. The wrong selection of collocation can be also attributed to the students' confusion between the various meanings of the same word in Arabic, which can literally be translated into various words. This led students to follow a literal method in translation, which did not only cause a great loss in the legal meaning, but also caused a great loss in the intended legal effect. The results also showed that the students committed huge mistakes in translating less technical collocations. The students' unfamiliarity with the semi-technical collocations, their lack of experience, and the close similarity among the terms led them to select the wrong equivalences. To overcome the difficulties they faced, the students relied on translating the collocations literally, which rendered wrong translation in most of the cases. Although the everyday vocabulary collocations are easy to translate as the translators have more freedom to select from a wide variety of resources, the students faced difficulties to render the accurate translation. The analysis of the students' production showed that the students' poor linguistic background and their misunderstanding of the legal context contributed greatly to committing such wrong translations. The difficulty of translating legal collocations by Arab student-translators are affirmed by Al Aqad (2014), who investigated the translation of 8 marriage contracts as legal documents from Arabic into English. Al Aqad arrived at a conclusion that it is impossible, even to experienced translators, to render accurate translation of legal text. The reasons of this difficult were ascribed by the researcher to the differences between the Arabic and English language systems in terms of the equivalences. The findings about the challenges that faced the student-translators in this study are also in agreement with Alhihi (2015), who examined the problems that might face translation practitioners while translating lexical words and expressions from English into Arabic in health documents. The researcher found that the collocations were translated inaccurately due to the first language interference and lack of understanding of the intended meaning of the source text. The difficulty of finding the equivalence was not the actual cause of these errors, but the translators' wrong selection of these equivalences was the real reason.

\section{Conclusion}

This study examined the performance of Iraqi EFL translator-students and the difficulties they faced in translating 15 legal collocations used in contract agreements. The findings of this study demonstrated that these students do have a number of problems in translating such legal collocations. These problems are related to the inability of the students to use the correct equivalences that achieve the legal meaning and the legal effect meant in the context of the text. This was apparent especially with the more technical collocations, such as 'turnkey', 'bill of lading', and others, which required them to use definite collocations. This problem was caused by the students' unfamiliarity with the legal terminology used in contract agreements. To overcome this problem, the students tended to use the literal translation that helped them to render the legal meaning, to an extent, but was not able in any way to reflect the correct legal effect intended by the given legal collocation. Using literal translation by the students, especially with purely technical collocations, led to a great loss of the legal effect of these collocations. Another problem recorded in this study is related to the students' inability to differentiate between the three categories of legal collocations. In most of the cases, they mixed the categories without noticing that these collocations are different. The students used everyday language collocations and applied them to all types of collocations including the technical ones. They were even unable to use the correct grammatical form. This problem took place as a result of the students' poor linguistic knowledge and the limited vocabulary repertoire, even at the level of everyday collocations. It is recommended that these students receive more specialized training courses on legal translation, which would increase their familiarity with legal translation in general and translation of contract agreements in particular. These courses would also improve their linguistic knowledge, pragmatic awareness, and vocabulary repertoire.

The findings in this section imply that the Iraqi students are still in need to develop their linguistic knowledge and pragmatic awareness of the everyday vocabulary, semi-technical collocations, and purely technical collocations in the source as well as the target languages. This will help them avoid committing translation mistakes once they are exposed to legal translation in general and contract agreements in particular. To do so, these students should attend specialized course that focus on teaching such kind of vocabulary and terminologies. They should also be practically exposed to translate various legal documents in various legal fields, such as courts, civil status, real estate, contracts, and bid 
documents. These students should also know that the use of literal translation is useful in certain occasions; however, this method cannot be relied upon completely as it does not achieve the legal effect realized by understanding the legal context of the collocation. According to Emery (1989), who compared the linguistic features of Arabic legal documentary texts with their English texts, maintained that student-translators should appreciate and be aware of the differences between English and Arabic discourses in relation to the structure and style. Accordingly, this awareness can help translators produce an acceptable translation of legal documents.

\section{References}

Al Aqad, Mohammed H. (2014). Translation of Legal Texts between Arabic and English: The Case Study of Marriage Contracts. Arab World English Journal, 5(2), 110-121.

Alaugab, Abdullah Mohammad. (2007). Benefits, barriers, and attitudes of Saudi female faculty and students toward online learning in higher education. (Dissertation), University of Kansas.

Alcaraz, E., \& Hughes, B. (2014). Legal translation explained. London: Routledge.

Alhihi, Nidal. (2015). Lexical Problems in English to Arabic Translation: A Critical Analysis of Health Documents in Australia. Arab World English Journal, 6(2), 316 -328.

Almaany.com. (2016). Almaany Online Dictionary. Retrieved 30 Oct, 2016

Benson, M., Benson, E., \& Ilson, R. (2009). The BBI combinatory dictionary of English: Your guide to collocations and grammar. London: John Benjamins Publishing.

Creswell, J. W. (2013). Research design: Qualitative, quantitative, and mixed methods approaches (4th ed.). Boston: Pearson Education, Inc.

El-Farahaty, H. (2016). Translating Lexical Legal Terms Between English and Arabic. International Journal for the Semiotics of Law - Revue internationale de Sémiotique juridique, 1-21. doi: 10.1007/s11196-016-9460-2

Emery, P.G. (1989). Legal Arabic Text: Implications for Translation. Babel, 35, 35-40.

Farghal, Mohammed, \& Shunnaq, Abdullah. (1992). Major problems in students' translations of English legal texts into Arabic. Babel, 38(4), 203-210.

Faris, A. A., \& Sahu, R. A (2013). The Translation of English Collocations into Arabic: Problems and Solutions. Journal of the College of Arts. University of Basra 64, 51-66.

Garzone, G. (2000). Legal translation and functionalist approaches: A contradiction in terms. ASTTI/ETI, 395-414.

Gay, L.R., \& Airasian, P. (2003). Education research:Competencies for Analysis and Applications. New Jersey: Pearson Education.

Harvey, M. (2002). What's so special about Legal Translation? Meta: Journal des traducteursMeta:/Translators' Journal, 47(2), 177-185.

Ilyas, Asim Ismail. (2015). A Critical Study of Three English-Arabic Internet Glossaries. Arab World English Journal, 6(4), 194-213.

Laybutt, B. E. (2009). A comparative corpus study between a genre of Written Sports Reports and a large reference corpus (MA Dissertation), University of Birmingham, England.

Mohammad, Abdel Karim, Alawi, Nabil, \& Fakhouri, Maram. (2010). Translating Contracts between English and Arabic: Towards a More Pragmatic Outcome. Jordan Journal of Modern Languages and Literature, 2(1), 1-28.

Reiß, K., \& Vermeer, H. J. (1984). Grundlegung einer allgemeinen Translationstheorie (Vol. 147): Walter de Gruyter.

Šarčević, S. (1997). New approach to legal translation: Kluwer Law International.

Shammas, Nafez Antonious. (2013). Collocation in English: Comprehension and Use by MA Students at Arab Universities. International Journal of Humanities and Social Science, 3(9), 107-122.

Webster Random House. (1998). Random House Webster's Unabridged Dictionary: New York: Random House. 